\title{
Characteristics of Culturable Microbial Community in Rhizosphere/Non-rhizosphere Soil of Potentilla Fruticosa Population in Alpine Meadow Elevation Gradient
}

\author{
Minxia Liu*, Bowen Li, Lu Xu and Ruixin Yu \\ College of Geography and Environmental Science, Northwest Normal University, Lanzhou, China
}

OPEN ACCESS

Edited by:

Rahul Mahadev Shelake,

Gyeongsang National University,

South Korea

Reviewed by:

Pankaj Prakash Verma,

Central Potato Research Institute

(ICAR), India

Sopan Ganpatrao Wagh,

Czech Academy of Sciences, Czechia

*Correspondence:

Minxia Liu

xiamin/@163.com

Specialty section:

This article was submitted to

Plant-Soil Interactions,

a section of the journal

Frontiers in Soil Science

Received: 14 July 2021 Accepted: 06 September 2021 Published: 05 October 2021

Citation:

Liu M, Li B, Xu L and Yu R (2021) Characteristics of Culturable Microbial

Community in

Rhizosphere/Non-rhizosphere Soil of Potentilla Fruticosa Population in Alpine Meadow Elevation Gradient. Front. Soil Sci. 1:741012.

doi: 10.3389/fsoil.2021.741012
Potentilla fruticosa is a typical shrub of alpine meadows with canopy effects that can greatly influence soil fertility and microbiological parameters. Changes in rhizosphere microorganisms can reflect the response of these plants to environmental changes. This study aimed to examine the rhizosphere and non-rhizosphere of $P$. fruticosa on the amount of selected microorganisms and main environmental factors at different elevation gradients $(3,000,3,250,3,500,3,750$, and 4,000 m). The results suggested that bacteria were predominant of the microbial soil community in the rhizosphere and non-rhizosphere, while fungi and actinomycetes represented the minority. With the increase of altitude, the total amount of microbial, bacteria, and actinomycetes in the rhizosphere and non-rhizosphere of $P$. fruticosa showed a downward trend, and microbial functional groups showed that the "hump shape" changed, but the fungi showed the opposite. Variance inflation factor (VIF) screening environmental factors and path analysis were obtained. In the rhizosphere soil, bacteria were affected by Soil organic carbon (SOC), and soil bulk density (SBD) became the main environmental limiting factor with the increase of altitude. The main environmental limiting factor of actinomycetes changed from SBD to Soil total (ST). In the non-rhizosphere soil, the bacteria and actinomycetes changed from ST to SOC and SBD, respectively. The main environmental limiting factor of the fungi was SOC in the rhizosphere and non-rhizosphere. Soil water content (SWC) was the main environmental determinant factor for all microbial groups, microbial functional groups were related to Soil total nitrogen (STN). Our results help to understand the relationship between nutrient cycling and the ecosystem function of alpine meadow plant soil microorganisms and provide theoretical support for alpine meadow ecosystem restoration, biodiversity protection, and the use of microbial resources.

Keywords: alpine meadow, elevation gradients, rhizosphere soil, culturable microbial, Qinghai-Tibet plateau

\section{INTRODUCTION}

The rhizosphere is the narrow zone of soil surrounding the root that is under the immediate influence of the root system (1). This zone is rich in nutrients when compared with the bulk soil, due to the accumulation of a variety of organic compounds released from roots by exudation, secretion, and deposition (2). The area surrounding growing plant roots in soil (the rhizosphere) represents 
a critical hotspot for biogeochemical transformation that underlies the process of soil formation, carbon cycling, and the ultimate productivity of the earth's terrestrial ecosystems (3). Rhizosphere microorganisms play an important role in plant growth, diversity change, and ecosystem function represent the health status of plant growth (4). As a potential nurse plant, Potentilla fruticosa plays an important role in the natural growth of other species below the canopy $(5,6)$. Xu et al. (7) have shown that the graminoid functional group was the most intensely and significantly affected by the rhizosphere effect of the foundation shrub $P$. fruticosa. At the same time, the growth of rhizosphere microorganisms was also affected by the P. fruticosa, which kept the rhizosphere microbial activity at a high level (8). For example, Eisenhauer et al. (9) found that plant diversity will increase the biomass and activity of soil microorganisms, thus affecting the soil carbon and nitrogen cycle, which in turn has a feedback effect on plant communities. Butterfield et al. (10) found that conservation plants play an important role in maintaining biodiversity in harsh environments. Ballantyne and Pickering (11) also found in Australia that the Epacris gunnii (nurse plant) can change the composition of plant communities, improve soil fertility, and promote soil quality.

Many of the current insights into interactions and processes in the rhizosphere have emerged from studies on agricultural or horticultural crop plants and model species such as Arabidopsis thaliana and Medicago truncatula (12). However, considerable progress is also being made in understanding the microbial ecology of the rhizosphere of non-cultivated plant species in natural ecosystems (13): temperature and moisture $(14,15)$, metal stress $(16,17)$, soil management $(18)$, phosphorus enrichment, and nitrogen availability $(19,20)$. To better understand the players and processes that operate in the rhizosphere, a variety of molecular techniques, such as metagenomics and stable-isotope probing, have been applied over the past decade (21-24). Nevertheless, traditional methods of microbial culture still have some availability today. França et al. (25) found that the effect of altitude and season on abundance and diversity of the culturable heterotrophic bacterial and yeast community was examined at four forest sites. Francesco et al. (18) found that soil culturable microorganisms were affected by different soil managements in a 2 year wheat-faba bean rotation. Soil nutrient contents significantly influenced the abundance and diversity of culturable bacteria, but not of culturable yeasts.

As the third pole of the world, the Qinghai-Tibet Plateau has formed unique habitats, and its complex and diverse ecological system make soil microorganism species diverse. The difference in altitude will change the temperature, humidity, and other environmental factors, resulting in the change of soil environment and thus affect the ecological processes of rhizosphere microorganisms (26). This provides a unique opportunity to investigate the change of rhizosphere and nonrhizosphere microorganisms in $P$. fruticosa on different altitude gradients. The relationship between microbial communities and plants can be better understood by studying the changes of rhizosphere and non-rhizosphere microorganisms in the altitude gradient. Here, we focus on the alpine community from the Qinghai-Tibet plateau, rhizosphere, and non-rhizosphere microorganism changes of $P$. fruticosa are affected by many factors. This study aimed to: (1) examine the effects of elevation in the rhizosphere and non-rhizosphere microorganisms of Potentilla fruticose; (2) identify major environmental factors affecting rhizosphere and non-rhizosphere microorganisms at different altitudes.

\section{MATERIALS AND METHODS Study Area}

This study was carried out at the Research Station of the Alpine Meadow Ecosystem of Lanzhou University, located in Maqu county, Gansu, in the eastern part of the Qinghai-Tibetan plateau, China $\left(\mathrm{N} 33^{\circ} 40^{\prime}, \mathrm{E} 101^{\circ} 52^{\prime}\right)$. The region has mean annual precipitation of $650 \mathrm{~mm}$, and altitudes range from 2,985 to $4,021 \mathrm{~m}$, the mean annual temperature is $1.2^{\circ} \mathrm{C}$, the average temperature in January is $-10.7^{\circ} \mathrm{C}$, the average temperature in July is $11.7^{\circ} \mathrm{C}$, the annual accumulated temperature of $\geq 0^{\circ} \mathrm{C}$ is $1,732^{\circ} \mathrm{C}$, the average annual frost period is not $<270$ days. The surface runoff is $200-350 \mathrm{~mm}$ deep, and the annual evaporation is $1,222 \mathrm{~mm}$. The soils in this area are sub-alpine meadow soil. The plot of the study area is shown in Figure $\mathbf{1 .}$

\section{Experimental Design and Soil Sampling}

Between July and September 2019, all the selected fields seem to have the same environmental (northern slope) and historical conditions and no grazing system. Nine quadrats of $1 \times 1 \mathrm{~m}$ were randomly placed in each plot along an elevation gradient of 3,000, 3,250, 350, 3,750, and 4,000 $\mathrm{m}$ on three hills (Figure 1). A total of 135 quadrats were investigated. The traditional shaking off method was used for rhizosphere soil sampling $(27,28)$. In the selected quadrat, select the well-growing $P$. fruticosa, dig the complete root system of $P$. fruticosa without damaging the root system, gently shake off the large soil on the root system, and then gently brush off the soil attached to the root surface with a brush, and remove the visible roots in the soil sample, which is the rhizosphere soil of the $P$. fruticosa population. For non-rhizosphere soil, take soil samples within $0-15 \mathrm{~cm}$ vertically from the ground outside the rhizosphere projection range of $P$. fruticosa. A total of 270 rhizosphere/non rhizosphere soil samples were collected. Part of the sample was stored at $4^{\circ} \mathrm{C}$ and used for microbial analysis. The other sample was air-dried for analyzing soil physical and chemical properties. The basic situation of the study area is shown in Table $\mathbf{1 .}$

\section{Microbial Population Count}

The microbial populations (bacteria, fungi, and actinomycetes) were determined by suspending $10 \mathrm{~g}$ of each soil sample in $90 \mathrm{ml}$ of sterile phosphate buffer $(0.1 \mathrm{M}, \mathrm{pH}$ 6.8) and shaking vigorously at $270 \mathrm{rpm}$ for $1 \mathrm{~h}$. Then, $100 \mu \mathrm{l}$ from several 10 -fold serial dilutions $\left(10^{-1}-10^{-6}\right)$ of each sample were spread onto plates. Seeded plates were incubated in the dark, at 28 and $37^{\circ} \mathrm{C}$, and colonies of total culturable fungi and total culturable bacteria were counted after 4-5 and 2-3 days incubation, respectively. Colonies of total culturable actinomycetes were counted after 5-7 days incubation and expressed as $\log (\mathrm{CFU}+1) / \mathrm{g}$ of dry soil $(\mathrm{CFU}=$ Colony Forming Unit). We added 1 to 


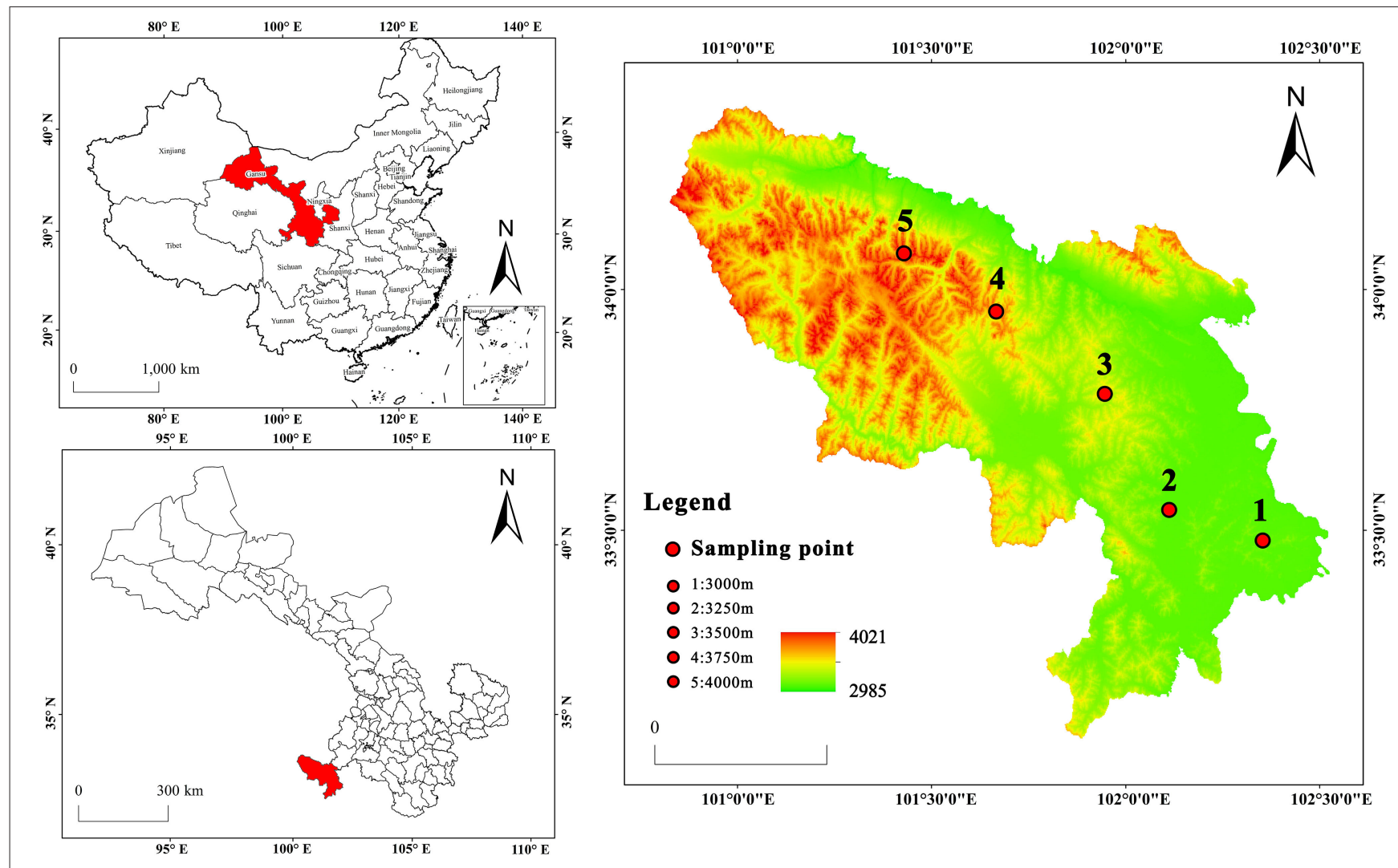

FIGURE 1 | Plot of the study area.

each CFU number to avoid negative log values. Azotobacter used Ashby's medium, ammonifier used beef extract peptone AGAR medium, nitrifier used Stephenson medium. The amount of soil microbial functional groups was determined by the MPN method.

\section{Determination of Soil Properties}

Soil samples were air-dried and then passed through a $0.15-\mathrm{mm}$ sieve prior to analysis (with three replicates for each soil core). Soil water content (SWC) was measured by oven drying the samples at $105^{\circ} \mathrm{C}$. Soil $\mathrm{pH}$ was determined using 2.5:1 water to air-dried soil ratio and a standard $\mathrm{pH}$ meter. Soil total nitrogen (STN) was determined in airdried homogenized $0.5 \mathrm{~g}$ soil samples digested with sulfuric acid and a $\mathrm{K}_{2} \mathrm{SO}_{4}: \mathrm{CuSO}_{4}:$ Se catalyst and analyzed using a SmartChem 200 discrete chemistry analyzer (29). Soil total phosphorus (STP) was determined by the $\mathrm{H}_{2} \mathrm{SO}_{4}-\mathrm{HClO}_{4}$ fusion method (30). Soil organic carbon (SOC) was determined via a potassium dichromate oxidation method (31). We measured concentrations of available nitrogen (SAN) and available phosphorus (SAP) with a SmartChem Discrete Auto Analyser. Urease (URE) was determined by the phenolsodium hypochlorite colorimetric method, and catalase (CAT) was determined by the potassium permanganate titration method (32).

\section{Statistical Analysis}

Data processing and path analyses were performed with SPSS version 20.0 statistical software (SPSS, Chicago, USA), giving the direct path coefficients and the indirect path coefficient of each factor. Then the coefficients of determination were calculated using correlation coefficients and direct path coefficients $(33,34)$. Using the method of the least significant difference (LSD) to examine the differences between mean values at a value of $p$ $<0.05$. Using vegan package vif.cca function (VIF, variance inflation factor) to screen environmental factors by $\mathrm{R}$ software (version 2.15.3) and graphing with Graphpad Prism software (version 7.02).

\section{RESULTS}

\section{Microbial Amount of Rhizosphere and Non-rhizosphere Soil}

Table 2 showed that the bacteria were predominant in the microbial soil community, while the fungi and actinomycetes represented the minority. With the increase of altitude, the total amount of microbial, bacteria, and actinomycetes in the rhizosphere and non-rhizosphere soil showed a downward trend. The fungi showed fluctuating increases and the amount was least at $3,250 \mathrm{~m}$. The total microbial functional groups, azotobacter, ammonifier, and nitrifier showed "hump-shape" in 
TABLE 1 | Overview of the study area.

\begin{tabular}{|c|c|c|c|c|c|}
\hline $\begin{array}{l}\text { Altitudes } \\
\text { (m) }\end{array}$ & $\begin{array}{l}\text { Latitude/ } \\
\text { Longitude }\end{array}$ & Slope $\left({ }^{\circ}\right)$ & $\begin{array}{l}\text { Plant } \\
\text { biomass } /\left(g \cdot \mathrm{m}^{2}\right)\end{array}$ & Richness & $\begin{array}{l}\text { Dominant species (Important } \\
\text { value }>0.1 \text { ) }\end{array}$ \\
\hline 3,000 & $\begin{array}{l}33^{\circ} 28^{\prime} 19^{\prime \prime} \mathrm{N} / \\
102^{\circ} 20^{\prime} 37^{\prime \prime} \mathrm{E}\end{array}$ & $27 \pm 0.05 c$ & $34.48 \pm 1.74 c$ & $37.82 \pm 1.17 d$ & $\begin{array}{l}\text { P. fruticosa, Festuca ovina, Anemone } \\
\text { rivularis, Koeleria cristata, Ligularia } \\
\text { virgaurea }\end{array}$ \\
\hline 3,250 & $\begin{array}{l}33^{\circ} 33^{\prime} 08^{\prime \prime} \mathrm{N} / \\
102^{\circ} 14^{\prime} 42^{\prime \prime} \mathrm{E}\end{array}$ & $31 \pm 0.01 d$ & $34.73 \pm 0.97 e$ & $35.92 \pm 2.13 a$ & $\begin{array}{l}\text { P. fruticosa, Kobresia myosuroides, } \\
\text { Gentiana macrophylla, Koeleria } \\
\text { cristata }\end{array}$ \\
\hline 3,500 & $\begin{array}{l}33^{\circ} 47^{\prime} 26^{\prime \prime} \mathrm{N} / \\
101^{\circ} 53^{\prime} 02^{\prime \prime} \mathrm{E}\end{array}$ & $28 \pm 0.12 a$ & $46.63 \pm 2.29 a$ & $39.51 \pm 2.06 b$ & $\begin{array}{l}\text { P. fruticosa, Kobresia myosuroides, } \\
\text { Gentiana macrophylla, Festuca ovina, } \\
\text { Anemone coelestina, Koeleria cristata }\end{array}$ \\
\hline 3,750 & $\begin{array}{l}33^{\circ} 56^{\prime} 49^{\prime \prime} \mathrm{N} / \\
101^{\circ} 48^{\prime} 37^{\prime \prime} \mathrm{E}\end{array}$ & $27 \pm 0.02 d$ & $39.01 \pm 2.21 b$ & $38.11 \pm 0.87 e$ & $\begin{array}{l}\text { P. fruticosa, Ligularia virgaurea, } \\
\text { Gentiana macrophylla, Koeleria } \\
\text { cristata }\end{array}$ \\
\hline 4,000 & $\begin{array}{l}34^{\circ} 05^{\prime} 23^{\prime \prime} \mathrm{N} / \\
101^{\circ} 24^{\prime} 33^{\prime \prime} \mathrm{E}\end{array}$ & $30 \pm 0.08 b$ & $34.02 \pm 1.35 d$ & $35.02 \pm 2.01 c$ & $\begin{array}{l}\text { P. fruticosa, Koeleria cristata, } \\
\text { Oxytropis kansuensis }\end{array}$ \\
\hline
\end{tabular}

Different letters in the same column indicate significant differences $(p<0.05)$.

the rhizosphere and non-rhizosphere soil. The bacteria and fungi in the rhizosphere were higher than that of the non-rhizosphere, but the actinomycetes were the opposite. The azotobacter, ammonifier, and nitrifier in the rhizosphere were higher than that of the non-rhizosphere at every elevation gradient.

\section{Rhizosphere and Non-rhizosphere Soil Physical and Chemical Factors}

Figure 2 showed that with the increase of altitude, SOC, SAP, soil bulk density (SBD), and $\mathrm{pH}$ in rhizosphere soil showed an upward trend, ST, SC, and STP showed a downward trend, while SWC, SAN, URE, STN, and CAT showed a "hump-shape" change. Soil organic carbon, STP, and $\mathrm{pH}$ in non-rhizosphere soil showed an upward trend, SBD, SC, and ST showed a downward trend, while SWC, STN, SAP, CAT, and URE showed "humpshape" change. Soil nutrient content and SWC in rhizosphere soil were higher than that of non-rhizosphere, and SC, URE, $\mathrm{pH}$ were the opposite. Except for 3,000 and 3,500 m, the SBD in the rhizosphere soil was higher than that of non-rhizosphere, SC and CAT in the rhizosphere was higher than that of the non-rhizosphere at 3,000 and 3,750 m, respectively, ST had no significance between the rhizosphere and non-rhizosphere.

\section{Variance Inflation Between Soil Microorganisms and Environmental Factors}

The VIF test can be used to calculate the VIF-value of each environmental factor, and use this as the basis for judgment. In this paper, when the VIF-value is between 2.5 and 10 , it can be regarded as a useless environmental factor, to achieve the purpose of screening environmental factors. After selection, the SWC, SBD, SOC, and ST for the microorganisms in the rhizosphere soil of $P$. fruticose, the SWC, STN, ST, and URE for the microorganisms in the non-rhizosphere soil of $P$. fruticosa (Figure 3).

\section{Path Analysis Between Soil Microorganisms and Environmental Factors}

Path analysis is shown in Figure 4. In the rhizosphere soil of P. fruticosa, the bacteria are mainly affected by SOC. With the increase of altitude, SBD has gradually become the main environmental limiting factor. The actinomycetes changed from SBD to ST. In the non-rhizosphere soil of $P$. fruticosa, the bacteria and actinomycetes changed from ST to SOC and $\mathrm{SBD}$, respectively. The main environmental limiting factor of the fungi was SOC in the rhizosphere and non-rhizosphere. The three microbial functional groups were similar, STN is the main environmental limiting factor in the rhizosphere and nonrhizosphere with altitude increase. Soil water content is the main environmental determining factor, which has no significant change with the increase of altitude.

\section{DISCUSSION}

Rhizosphere microorganisms can directly and/or indirectly affect the composition and biomass of plant communities in natural ecosystems $(35,36)$. Numerous organisms contribute to these processes, leading to countless interactions between plants, antagonists, and mutualistic symbionts, both below ground and above ground (37-39). There are some very important groups in soil microorganisms, such as Trichoderma, which belongs to antagonistic fungi (40). Bacillus and Pseudomonas are bacteria with plant growth promoting activity. Rhizobia and slow growing rhizobia can establish a symbiotic relationship with legumes, while nitrogen fixing bacteria show asymmetric nitrogen fixation characteristics (41). Cultivation-based methods might also be more sensitive to retrieve changes of the physiologic and metabolic state of the community due to environmental fluctuations since the culturable fraction of the community might react more rapidly to changes in biotic and abiotic factors than genomic surveys that mainly target DNA fragments derived 


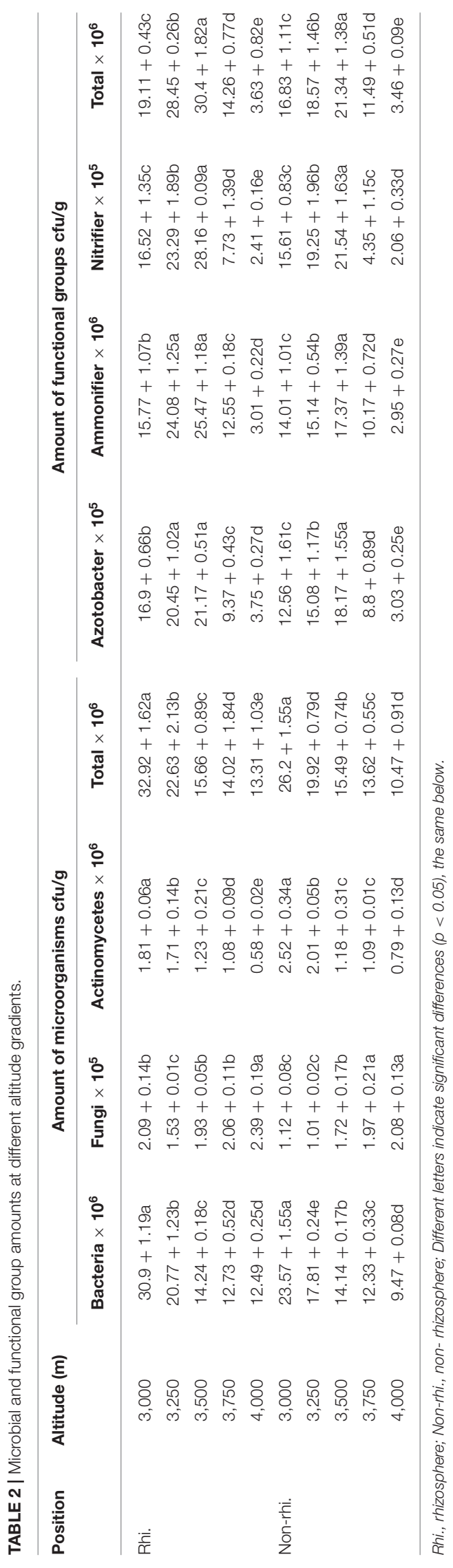

from viable and non-viable organisms (42). The data obtained in our study demonstrate a lower amount of fungi in the rhizosphere and non-rhizosphere of the P. fruticosa at $3,250 \mathrm{~m}$. The possible reason is that the slope $\left(31^{\circ}\right)$ at this altitude is large, resulting in serious soil erosion, so the number of fungi is small (43). The actinomycetes are related to the demand and adaptability for water, $\mathrm{pH}$, heat, and nutrients, different altitude leads to changes in the regional environment, this is also consistent with Huang's studies (44). Previous studies have shown that SWC in the rhizosphere of $P$. fruticosa is higher than that in the non rhizosphere $(7,45)$, higher SWC limits the growth of actinomycetes, which also explains that the number of actinomycetes in rhizosphere soil is lower than that in nonrhizosphere soil.

Due to the canopy effect of $P$. fruticosa, the soil moisture is kept high, which is conducive to the growth of bacteria and fungi (46). Water and temperature can influence the growth of plants, which in turn can affect microbes, so the amount of three microbial functional groups showed largest at $3,500 \mathrm{~m}$ in rhizosphere and non-rhizosphere. With the increase of altitude, the rhizosphere of $P$. fruticosa had more significant advantages in cold resistance than non-rhizosphere, and rhizosphere microorganisms, which can still maintain great survival abilities at high altitudes. Therefore, the growth of microbial functional groups in the rhizosphere soil of $P$. fruticosa was better than that of the non-rhizosphere. In addition, nitrifiers are autotrophic aerobic bacteria, low oxygen content in the non-rhizosphere soil of $P$. fruticosa is not conducive to the growth of nitrifiers $(47,48)$. We inferred that the amount of nitrifier was also related to the growth of $P$. fruticosa. Rhizosphere soil physical and chemical properties (especially soil nutrient content) are an important method of judging plant growth and microbial reproduction. Therefore, explaining the soil physicochemical mechanism in the regulating processes and dynamics of plants and microbial communities in more detail is crucial for understanding the responses of different plants to environmental change $(49,50)$. Microbial functional groups play an essential role, which can convert $\mathrm{N}_{2}$ to $\mathrm{NH}_{4}^{+}$in the process of plant growth. Potentilla fruticosa has a well-developed root system and it can absorb water from deeper places and promote the growth of other plants (51). At the altitude of $3,500 \mathrm{~m}$, the plant biomass and abundance in the study area are highest (Table 1). This also explains why the amount of microbial functional groups and SWC are the highest. The nutrient content in the rhizosphere soil (SOC, STN, STP, SAN, $\mathrm{SAP}$ ) of $P$. fruticosa was higher than that of non-rhizosphere, and the difference of soil nutrients becomes more significant with the increase of altitude. We inferred that the "fertile island effects" in the rhizosphere of $P$. fruticosa make the soil nutrients concentrated in the root, the amount of soil microorganisms in the rhizosphere is also large. As the elevation increases, the decrease of environmental temperature is not conducive to the growth of soil microorganisms. So there was little difference in the amount of rhizosphere and non-rhizosphere microorganisms among different plants (52). In addition, Li et al. (53) found that Graminoids can reduce the content of SOC. In this study area, Koeleria cristata is the dominant species and it is widely 


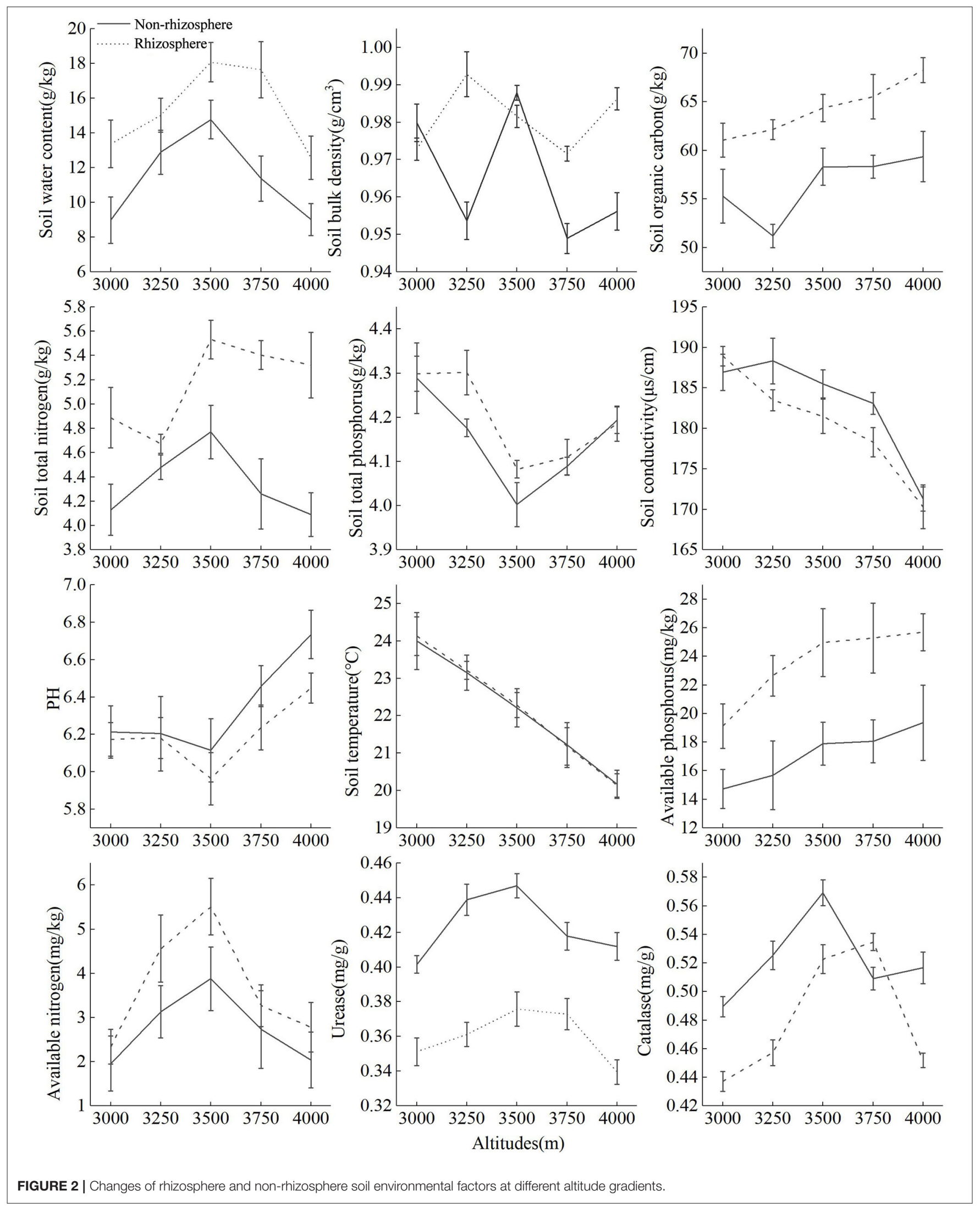




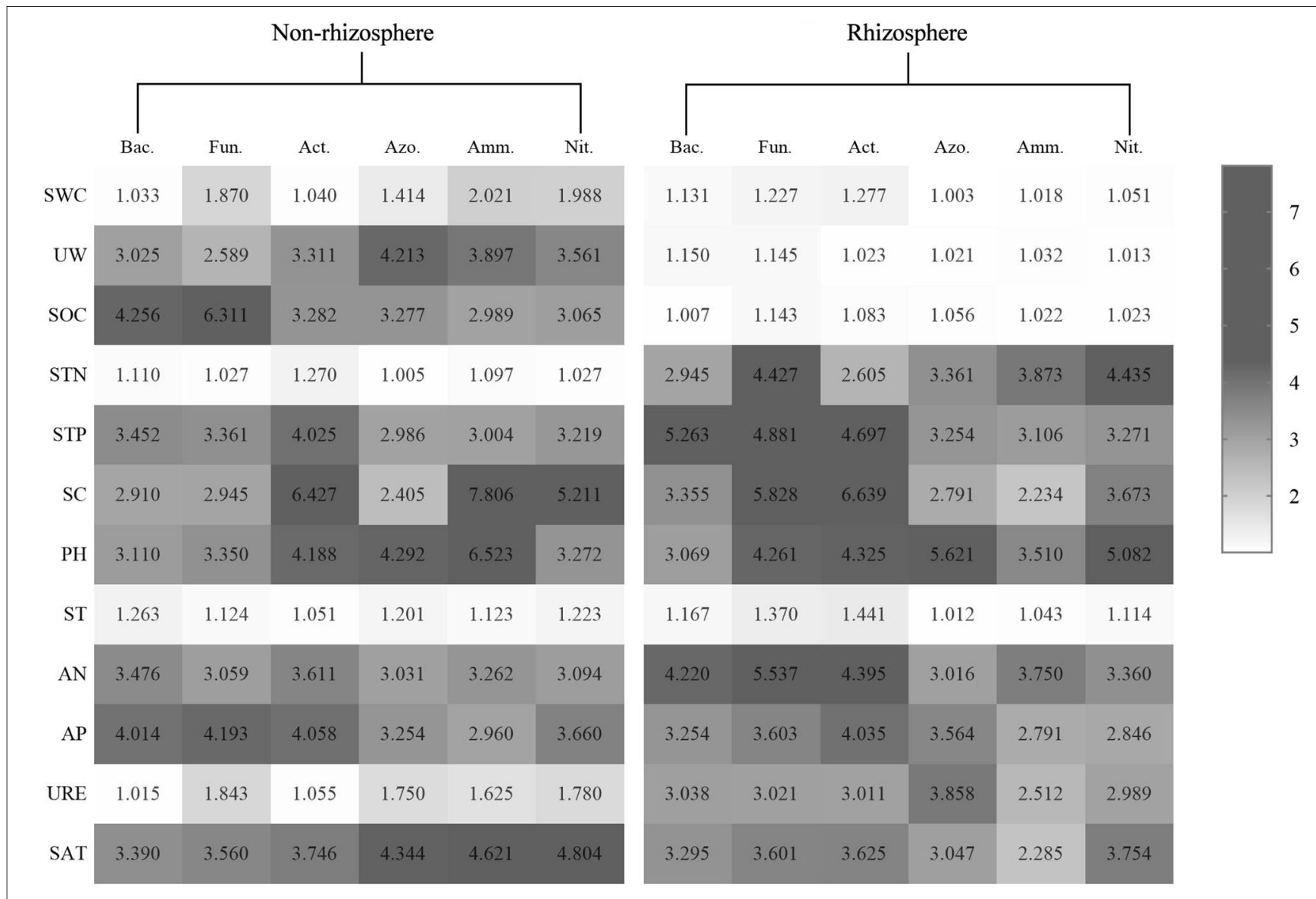

FIGURE 3 | Variance inflation of soil microorganisms and environmental factors in the rhizosphere and non-rhizosphere soil.

distributed outside the rhizosphere of $P$. fruticosa, which is the reason for the big difference of SOC between the rhizosphere and non-rhizosphere (53).

As plants and soil microbes are tightly linked by nutrient cycling (54), changes in soil physicochemical properties in response to altitude increase may thus affect the composition and functioning of microbial communities (55). Therefore, elucidating the soil physicochemical mechanism in regulating processes and the dynamics of plant and microbial communities in more detail is crucial for understanding the responses of ecosystem function to altitude increase. In this paper, the main environmental limiting factor for most microbial groups is ST. However, with the change of altitude, the environmental factors affecting microbial growth also change. In the rhizosphere soil, SBD was the main environmental factor limiting the growth of bacteria and actinomycetes in $3,500 \mathrm{~m}$. When the altitude was above $3,500 \mathrm{~m}, \mathrm{SBD}$ was the main environmental limiting factor for bacteria, when the altitude was below $3,500 \mathrm{~m}$, SBD was the main environmental limiting factor for actinomycetes. This is because, under the influence of the canopy effect and rhizosphere effect of the $P$. fruticosa (6), ST had little influence on rhizosphere microorganism, soil nutrient content is the main factor limiting bacteria growth. Meanwhile, nonrhizosphere soil is not conducive to the accumulation of organic matter, and the small soil porosity leads to the slow growth of actinomycetes (56). When the altitude reached 3,750 and $4,000 \mathrm{~m}$, the ST is low and the terrible environment leads to the slow growth of actinomycetes, so the ST becomes the main environmental limiting factor. The main environmental limiting factor affecting fungi did not change between the rhizosphere and non-rhizosphere, we speculate that fungi are related to the litter on the surface of the soil, and that a lot of litter makes the content of organic matter rich, which provides good nutritional conditions (54). Soil water content is of great significance to the growth of soil microorganisms and promotes the diversity of the microbial community (57). In this paper, the SWC in the study area is high, so it is the main determining factor for all microbial groups. In the functional groups of microorganisms, azotobacter convert $\mathrm{N}_{2}$ to $\mathrm{NH}_{4}^{+}$for plants to synthesize organic nitrogen and supplement nitrogen in grassland soil, ammonifier nitrate $\mathrm{NH}_{4}^{+}$to $\mathrm{NO}_{3}^{-}$, nitrifier convert $\mathrm{NO}_{3}^{-}$to $\mathrm{N}_{2}$ to complete the nitrogen cycle (58). All of these are related to soil nitrogen content, meaning STN is also a major factor affecting microbial functional groups. 


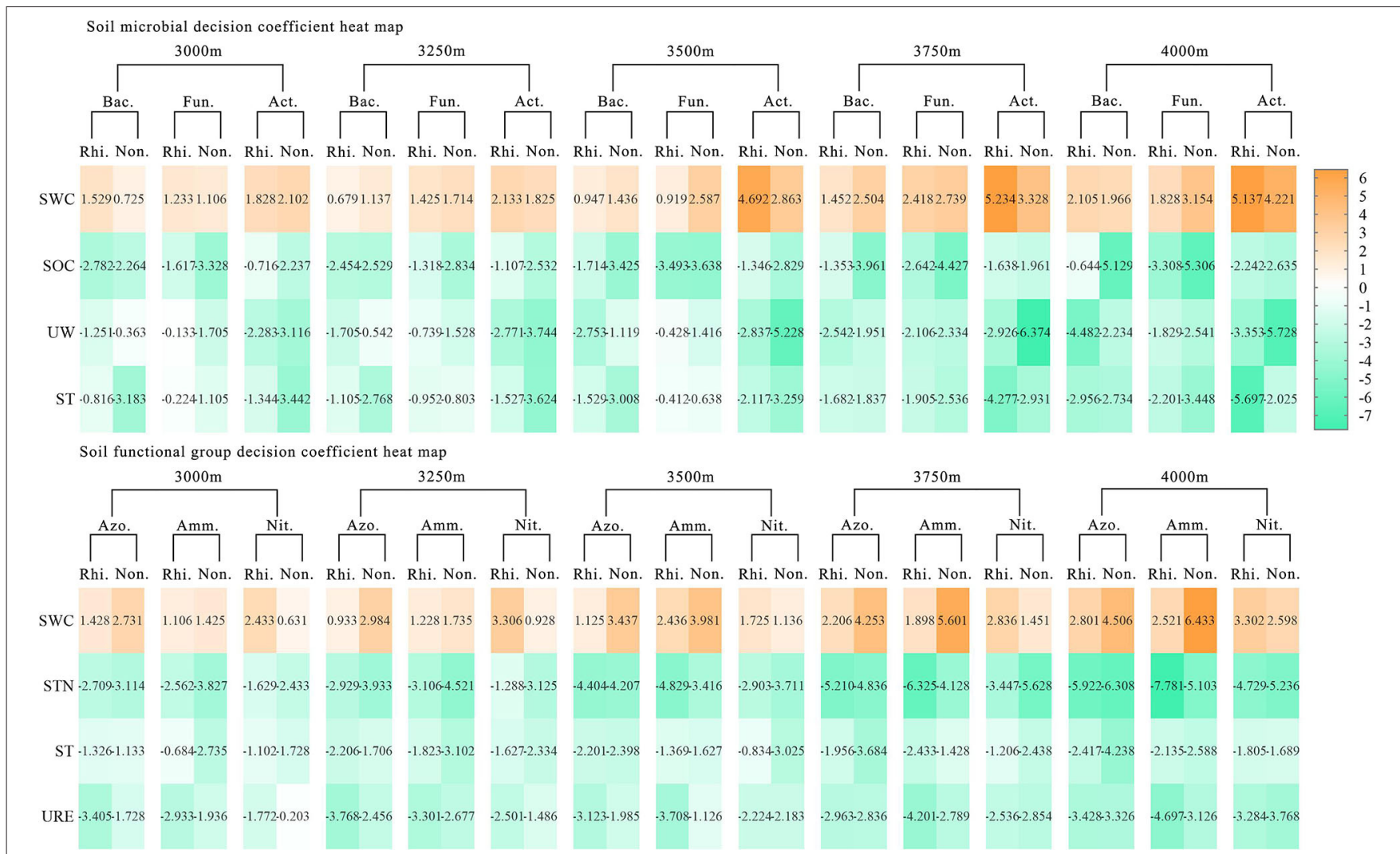

FIGURE 4 | Heat map of the decision coefficient of microorganisms and environmental factors in the rhizosphere and non-rhizosphere soil at different altitudes.

\section{CONCLUSION}

Bacteria were predominant in the microbial soil community, while fungi and actinomycetes represented the minority. As the elevation increases, bacteria and actinomycetes decreased in the rhizosphere and non-rhizosphere soil of $P$. fruticose. Microbial functional groups showed "hump-shape" change, the fungi showed "V-shaped" change. In the rhizosphere soil, bacteria were affected by SOC $(3,000$ and 3,250 $\mathrm{m})$, and SBD became the main environmental limiting factor $(3,500,3,750$, and 4,000 m). The main environmental limiting factor of actinomycetes changed from SBD to ST at $3,750 \mathrm{~m}$. In the non-rhizosphere soil, the bacteria and actinomycetes changed from ST to SOC at 3,500 m and SBD at $3,250 \mathrm{~m}$, respectively. Soil organic carbon was the main environmental limiting factor for fungi. Soil water content is the main determining factor for all microbial groups, microbial functional groups were related to STN.

\section{DATA AVAILABILITY STATEMENT}

The original contributions presented in the study are included in the article/supplementary material, further inquiries can be directed to the corresponding author/s.

\section{AUTHOR CONTRIBUTIONS}

ML: writing-review and editing. BL: data curation and writing-original draft. LX: visualization and investigation. RY: software and validation. All authors contributed to the article and approved the submitted version.

\section{FUNDING}

This study was supported by the National Natural Science Foundation of China (Grant no. 31760135).

\section{ACKNOWLEDGMENTS}

We sincerely appreciate the assistance provided by the Research Station of Alpine Meadow and Wetland Ecosystems of Lanzhou University in supporting this research. 


\section{REFERENCES}

1. Paul EA. Soil Microbiology, Ecology and Biochemistry. New York, NY: Academic Press (2014). p. 1-14. doi: 10.1016/B978-0-12-415955-6.00001-3

2. Dobbelaere S, Vanderleyden J, Okon Y. Plant growth-promoting effects of diazotrophs in the rhizosphere. Crit Rev Plant Sci. (2003) 22:10749. doi: 10.1080/713610853

3. Zhalnina K, Louie KB, Hao Z, Mansoori N, da Rocha UN, Shi SJ, et al. Dynamic root exudate chemistry and microbial substrate preferences drive patterns in rhizosphere microbial community assembly. Nat Microbiol. (2018) 3:470-80. doi: 10.1038/s41564-018-0129-3

4. Tang HM, Chao L, Xiao XP, Tang WG, Cheng KK, Pan XC, et al. Effects of different manure nitrogen input ratio on rhizosphere soil microbial biomass carbon, nitrogen and microbial quotient in double-cropping rice field. Chin J Appl Ecol. (2019) 30:1335-43. doi: 10.13287/j.1001-9332.201904.014

5. Michalet R, Chen SY, An LZ, Wang XT, Wang YX, Guo P, et al. Communities: are they groups of hidden interactions? J Veget Sci. (2015) 26:207-18. doi: 10.1111/jvs.12226

6. Wang XT, Michalet R, Chen SY, Zhao L, An LZ, Du GZ, et al. Contrasting understorey species responses to the canopy and root effects of a dominant shrub drive community composition. J Veget Sci. (2017) 28:1118-27. doi: 10.1111/jvs.12565

7. Xu J, Michalet R, Zhang J, Wang G, Chu C, Xiao S. Assessing facilitative responses to a nurse shrub at the community level: the example of Potentilla fruticosa in a sub-alpine grassland of northwest China. Plant Biol. (2010) 12:780-7. doi: 10.1111/j.1438-8677.2009.00271.x

8. Michalet R, Pugnaire FI. Facilitation in communities: underlying mechanisms, community and ecosystems implications. Funct Ecol. (2016) 30:3-9. doi: 10.1111/1365-2435.12602

9. Eisenhauer N, Migunova VD, Ackermann M, Ruess L, Scheu S, Rillig M. Changes in plant species richness induce functional shifts in soil nematode communities in experimental grassland. PLOS ONE. (2011) 6:e24087. doi: 10.1371/journal.pone.0024087

10. Butterfield BJ, Cavieres LA, Callaway RM, Cook BJ, Kikvidze Z, Lortie CJ, et al. Alpine cushion plants inhibit the loss of phylogenetic diversity in severe environments. Ecol Lett. (2013) 16, 478-486. doi: 10.1111/ele.12070

11. Ballantyne M, Pickering CM. Shrub facilitation is an important driver of alpine plant community diversity and functional composition. Biodivers Conserv. (2015) 24:1859-75. doi: 10.1007/s10531-015-0910-Z

12. Philippot L, Raaijmakers JM, Lemanceau P, van der Putten WH. Going back to the roots: the microbial ecology of the rhizosphere. Nat Rev Microbiol. (2013) 11:789-99. doi: 10.1038/nrmicro3109

13. Bever JD, Platt TG, Morton ER. Microbial population and community dynamics on plant roots and their feedbacks on plant communities. Annu Rev Microbiol. (2012) 66:265-83. doi: 10.1146/annurev-micro-092611-150107

14. Kuzyakov Y, Hill PW, Jones DL. Root exudate components change litter decomposition in a simulated rhizosphere depending on temperature. Plant Soil. (2007) 290:293-305. doi: 10.1007/s11104-006-9162-8

15. Zhou SM, Zhang M, Zhang KK, Yang XW, Wang CY. Effects of reduced nitrogen and suitable soil moisture on wheat (Triticum aestivum L.) rhizosphere soil microbiological, biochemical properties and yield in the Huanghuai Plain, China. J Integr Agric. (2020) 19:234-50. doi: 10.1016/S2095-3119(19)62697-3

16. Farinati S, Dalcorso G, Bona E, Corbella M, Furini A. Proteomic analysis of Arabidopsis halleri shoots in response to the heavy metals cadmium and zinc and rhizosphere microorganisms. Proteomics. (2009) 9:483750. doi: 10.1002/pmic. 200900036

17. Mishra J, Singh R, Arora NK. Alleviation of heavy metal stress in plants and remediation of soil by rhizosphere microorganisms. Front Microbiol. (2017) 8:1706. doi: 10.3389/fmicb.2017.01706

18. Francesco DM, Andreina T, Gennaro B, Giambattista D, Claudio C, Franco N. Soil culturable microorganisms as affected by different soil managements in a two year wheat-faba bean rotation. Appl Soil Ecol. (2020) 149:103533. doi: 10.1016/j.apsoil.2020.103533

19. Silva UC, Medeiros JD, Leite LR, Morais DK, Sara CO, Oliveira $\mathrm{CA}$, et al. Long-term rock phosphate fertilization impacts the microbial communities of maize rhizosphere. Front Microbiol. (2017) 8:1266. doi: $10.3389 /$ fmicb. 2017.01266
20. Andrea J, Marco K, Contosta AR, Serita F, Joshua S, Smith RG, et al. Minerals in the rhizosphere: overlooked mediators of soil nitrogen availability to plants and microbes. Biogeochemistry. (2018) 139:10322. doi: 10.1007/s10533-018-0459-5

21. Prosser JI, Rangel-Castro JI, Killham K. Studying plant-microbe interactions using stable isotope technologies. Curr Opin Biotechnol. (2006) 17:98102. doi: 10.1016/j.copbio.2006.01.001

22. Mendes R, Kruijt M, Bruijn ID, Dekkers E, Voort MVD, Schneider JHM, et al. Deciphering the rhizosphere microbiome for disease-suppressive bacteria. Science. (2011) 332:1097-100. doi: 10.1126/science.1203980

23. Lundberg DS, Lebeis SL, Paredes SH, Yourstone SG, Jase M, Stephanie T, et al. Defining the core Arabidopsis thaliana root microbiome. Nature. (2011) 488:86-90. doi: 10.1038/nature11237

24. Bulgarelli D, Rott M, Schlaeppi K, van Themaat EVL, Ahmadinejad $\mathrm{N}$, Assenza F, et al. Revealing structure and assembly cues for Arabidopsis root-inhabiting bacterial microbiota. Nature. (2012) 488:91-5. doi: 10.1038/nature11336

25. França L, Sannino C, Turchetti B, Buzzini P, Margesin R. Seasonal and altitudinal changes of culturable bacterial and yeast diversity in Alpine forest soils. Extremophiles. (2016) 20:855-73. doi: 10.1007/s00792-016-0874-2

26. Margesin R, Minerbi S, Schinner F. Long-term monitoring of soil microbiological activities in two forest sites in South Tyrol in the Italian Alps. Microb Environ. (2014) 29:277. doi: 10.1264/jsme2.ME14050

27. Zhang QR, Zhou QX, Ren LP, Zhu YG, Sun SL. Ecological effects of crude oil residues on the functional diversity of soil microorganisms in three weed rhizospheres. J Environ Sci. (2006) 18:1101-6. doi: 10.1016/S1001-0742(06)60046-6

28. Liu BR, Niu SF, Zhang WW. Effects of soil particle size on enzyme activities and the amount of soil microorganism in rhizosphere of Caragana korshinskii in desert steppe. Acta Ecol Sin. (2019) 39:91718. doi: 10.5846/stxb201810252309

29. Bao SD. Chapter 6. In: Soil Agrochemical Analysis. 3rd ed. Beijing: China Agricuture Press (2000). p. 99-113.

30. Olsen SR, Cole CV, Watanabe FS, Dean LA. Estimation of Available Phosphorus in Soils by Extraction With Sodium Bicarbonate. USDA Circular No. 939. Washington, DC: U.S. Department of Agriculture (1954). p. 19.

31. Nelson DW. Total carbon, organic carbon, and organic matter.In: Sparks DL, Page AL, Helmke PA, Loeppert RH, Soltanpour PN, Tabatabai MA, Johnston CT, Sumner ME, editors. Methods of Soil Analysis. Vol. 9. Madison, WI: Soil Science Society of America, Inc. (1996) p. 9611010. doi: 10.2136/sssabookser5.3.c34

32. Guan SY. Soil Enzyme and Its Research Methods. Beijing: Agriculture Press (1986).

33. Zhu D, Li SY, Ren YY, Niu GC, Wei WY, Wang Y. Analysis of mechanism of non-enzymatic browning of Physalis pubescens L. during fermentation Food Sci. (2016) 37:204-8.

34. Zhao DQ, Zhang M, Liu YP. Research on non-enzymatic browning of orange juice concentrate during storage. J Food Sci Biotechnol. (2018) 37:517-25.

35. Kardol P, Cornips NJ, van Kempen MML, Tanja Bakx-Schotman JM, van der Putten WH. Microbe-mediated plant-soil feedback causes historical contingency effects in plant community assembly. Ecol Monogr. (2007) 77:147-62. doi: 10.1890/06-0502

36. Schnitzer SA, Klironomos JN, HilleRisLambers J, Kinkel LL, Reich PB, Xiao $\mathrm{K}$, et al. Soil microbes drive the classic plant diversity-productivity pattern. Ecology. (2011) 92:296-303. doi: 10.1890/10-0773.1

37. Bennett, A. E., and Bever, J. D. (2007). Mycorrhizal species differentially alter plant growth and response to herbivory. Ecology. 88:210-8. doi: 10.1890/00129658(2007)88[210:MSDAPG]2.0.CO;2

38. Behie SW, Zelisko PM, Bidochka MJ. Endophytic insect-parasitic fungi translocate nitrogen directly from insects to plants. Science. (2012). 336:15767. doi: $10.1126 /$ science. 1222289

39. Vannette RL, Rasmann S. Arbuscular mycorrhizal fungi mediate belowground plant-herbivore interactions: a phylogenetic study. Funct Ecol. (2012) 26:1033-42. doi: 10.1111/j.1365-2435.2012.02046.x

40. Chilosi G, Aleandri MP, Luccioli E, Stazi SR, Vannini A. Suppression of soil-borne plant pathogens in growing media amended with espresso spent coffee grounds as a carrier of Trichoderma spp. Sci Hortic. (2020) 259:108666. doi: 10.1016/j.scienta.2019.108666 
41. Ramakrishna W, Yadav R, Li K. Plant growth promoting bacteria in agriculture: two sides of a coin. Appl Soil Ecol. (2019) 138:108. doi: 10.1016/j.apsoil.2019.02.019

42. Smit E, Leeflang P, Gommans S, van den Broek J, van Mil S, Wernars K. Diversity and seasonal fluctuations of the dominant members of the bacterial soil community in a wheat field as determined by cultivation and molecular methods. Appl Environ Microbiol. (2001) 67:2284-91. doi: 10.1128/AEM.67.5.2284-2291.2001

43. Lin YT, Whitman WB, Coleman DC, Shi SY, Tang SL, Chiu CY. Changes of soil bacterial communities in bamboo plantations at different elevations. FEMS Microbiol Ecol. (2015) 91:fiv033. doi: 10.1093/femsec/fiv033

44. Huang ZQ, Yang LP, Xu W. Characteristics of soil actinomycetes in vertical distribution belts of vegetation in Mabian county of Sichuan. J Sichuan Forest Sci Technol. (2014) 35:73-6. doi: 10.3321/j.issn:0001-6209.2004.06.006

45. Yu W, Zhang L, Wang QL. Microbiological traits of the soil quality of Potentilla fruticosa shrub meadow in Qinghai-Tibetan Plateau. Acta Agrest Sin. (2016) 24:1248-53.doi: 10.11733/j.issn.1007-0435.2016.06.014

46. Zhao J. Effect of stocking rates on soil microbial number and biomass in steppe. Acta Agrestia Sin. (1999) 7:222-7.

47. Elizabeth B, Deanna N, Claudia W, Kari D. Residue management leading to higher field-scale $\mathrm{N}[[\mathrm{sb}]] 2[[/ \mathrm{s}]] \mathrm{O}$ flux is associated with different soil bacterial nitrifier and denitrifier gene community structures. Appl Soil Ecol. (2016) 108:288-99. doi: 10.1016/j.apsoil.2016.09.008

48. He WM, Kim YJ, Ko D, Yun S, Jun SC. Changes in soil N[[sb]]2[[/s]]O and $\mathrm{CH}[[\mathrm{sb}]] 4[[/ \mathrm{s}]]$ emissions and related microbial functional groups in an artificial CO[[sb]]2[[/s]] gassing experiment. Sci Total Environ. (2019) 6:40-9. doi: 10.1016/j.scitotenv.2019.06.400

49. Miao XP, Cheng JR, Wei Z, Zheng XC, Xin HH. Responses mechanism of $\mathrm{C}: \mathrm{N}: \mathrm{P}$ stoichiometry of soil microbial biomass and soil enzymes to climate change. Chin J Appl Ecol. (2018) 29:2445-54. doi: 10.13287/j.1001-9332.201807.041

50. Yuan X, Niu D, Weber-Grullon L, Fu H. Nitrogen deposition enhances plantmicrobe interactions in a semiarid grassland: the role of soil physicochemical properties. Geoderma. (2020) 373:114446. doi: 10.1016/j.geoderma.2020. 114446

51. Du BM, Kang H, Pumpanen J, Zhu P, Liu C. Soil organic carbon stock and chemical composition along an altitude gradient in the Lushan Mountain, subtropical China. Ecol Res. (2014) 29:433-9. doi: 10.1007/s11284-014-1 135-4
52. Zhu XM, Mao LJ, Chen BL. Driving forces linking microbial community structure and functions to enhanced carbon stability in biochar-amended soil. Environ Int. (2019) 133:105211. doi: 10.1016/j.envint.2019.105211

53. Li JH, Zhang H, Li WJ, Knops JMH. Plant-soil feedbacks in a sub-alpine meadow ecosystem with high plant diversity on the Qinghai-Tibetan Plateau. Plant Ecol. (2015) 216:1659-74. doi: 10.1007/s11258-015-0549-6

54. Han SZ, Gao R, Ma HL, Lu JF, Liu GH. Soil fungal biomass characteristics and influencing factors in subtropical forests. J Subtrop Resour Environ. (2014) 9:45-52. doi: 10.1016/j.chnaes.2015.12.004

55. Averill C, Waring B. Nitrogen limitation of decomposition and decay: how can it occur? Glob Chang Biol. (2018) 24:1417-27. doi: 10.1111/gcb.13980

56. Huang GY, Zhou X, Guo G, Ren C, Hu H. Variations of dissolved organic matter and $\mathrm{Cu}$ fractions in rhizosphere soil induced by the root activities of castor bean. Chemosphere. (2020) 254:126800. doi: 10.1016/j.chemosphere.2020.126800

57. Zhao GH, Li ZZ, Hu SJ, Chen XF, Gong B. The relationship among soil physicochemical properties and microorganisms and phytocommunity in Yongcheng Lake Wetland. J Northwest Forest Univ. (2020) 35:240-8. doi: 10.1007/BF02873086

58. Wang GR, Chen XR, Zhang JZ, Han YZ, Hu YG, Yang CD, et al. The temporal and spatial distribution of soil microorganism physiological floras in alpine shrubs of the eastern Qilian mountains. Acta Pratacult Sin. (2011) 20:31-8.

Conflict of Interest: The authors declare that the research was conducted in the absence of any commercial or financial relationships that could be construed as a potential conflict of interest.

Publisher's Note: All claims expressed in this article are solely those of the authors and do not necessarily represent those of their affiliated organizations, or those of the publisher, the editors and the reviewers. Any product that may be evaluated in this article, or claim that may be made by its manufacturer, is not guaranteed or endorsed by the publisher.

Copyright (c) $2021 \mathrm{Liu}, \mathrm{Li}, \mathrm{Xu}$ and $\mathrm{Yu}$. This is an open-access article distributed under the terms of the Creative Commons Attribution License (CC BY). The use, distribution or reproduction in other forums is permitted, provided the original author(s) and the copyright owner(s) are credited and that the original publication in this journal is cited, in accordance with accepted academic practice. No use, distribution or reproduction is permitted which does not comply with these terms. 